\title{
WHAT IS A SOURCE? OR, HOW SHAKESPEARE READ HIS MARLOWE
}

\author{
LAURIE MAGUIRE AND EMMA SMITH
}

But peradventure some man will denie that this was done by imitation, seeing the thinges be not all one in both the writers. I answere that imitation is not in things that be all one, but in things that be like, and that which is like, must be, not the same, but another thing.

(Johannes Sturm, A Rich Storehouse (I 570), sig.Hiv)

At our feast wee had a play called Twelve Night, or What You Will, much like the Commedy of Errores, or Menaechmi in Plautus.

(John Manningham's Diary, 2 Feb I6o I, p. I 8)

I'll have these players / Play something like the murder of my father.

(Hamlet, 2.2.596-7)

In their edition of The Tempest, Virginia and Alden Vaughan conclude that "scholars will probably never be able to identify with much confidence the numerous narrative, psychological and thematic threads that Shakespeare wove into The Tempest' (pp. I48-9). ${ }^{2}$ They are less optimistic than Kenneth Muir, identifying the play in 1957 as one where the 'Main Source' is 'Not known' with the expectant 'it is highly probable that there was a main source as yet unidentified'. ${ }^{3}$ Finding the source (or a source) of The Tempest has become not only a holy grail but something of a scholarly niche of the Shakespeare industry. Journals regularly include essays with Darwinian titles that claim 'A Source for The Tempest', 'The Tempest... . A New Source' or the more cautious and circumscribed 'A Possible Source of a Passage in The Tempest' (our emphasis). ${ }^{4}$ In the last few years alone Austen Saunders has proffered Richard Cosin's Conspiracie for Pretended
Reformation (I592) as a source for the moment when Shakespeare's shipwrecked Italians exclaim over their miraculously dry clothes; Todd Borlik has proposed the life of the Anglo-Saxon hermit and fen-dweller St Guthlac, described in medieval saints' lives and dramatized in a lost Elizabethan play, as the source of both plot and character (Prospero and Caliban); and the Vaughans have revised their Arden 3 edition of the play to include a

I Johannes Sturm, A Ritch Storehouse or Treasury for Nobilitye and Gentlemen (London, I 570); Diary of John Manningham, ed. John Bruce, Camden Society (London, I868); with the exception of The Tempest, all Shakespeare quotations are from the Oxford Complete Works, ed. Stanley Wells and Gary Taylor, 2nd edn (Oxford, 2005).

2 William Shakespeare, The Tempest, ed. Virginia Mason Vaughan and Alden T. Vaughan (London, I999, rev. 201 I).

3 Kenneth Muir, Shakespeare's Sources (London, I957), pp. 2557; p. 261. The other two sourceless plays are A Midsummer Night's Dream and Love's Labour's Lost.

4 These titles come from: William W. E. Slights, 'A Source for The Tempest and the Context of the Discorsi', Shakespeare Quarterly, 36 (I985), 68-70; Gary Schmidgall, 'The Tempest and Primalaeon: A New Source', Shakespeare Quarterly, 37 (I986), 423-39; Paul F. Cranefield and Walter Federin, 'A Possible Source of a Passage in The Tempest', Shakespeare Quarterly, I4 (I963), 90-2. Other articles make their claim with interrogatives or variant vocabulary ('influence', 'genesis'). See Gail Kern Paster, 'Montaigne, Dido and The Tempest: "How Came that Widow Dido in?"', Shakespeare Quarterly, 35 (I984), 9I-4; Richard Hillman, 'Chaucer's Franklin's Magician and The Tempest: An Influence Beyond Appearance', Shakespeare Quarterly, 34 (I983), 426-32; and W. Stacey Johnson, 'The Genesis of Ariel', Shakespeare Quarterly, 2 (I95I), $205-10$. 


\section{LAURIE MAGUIRE AND EMMA SMITH}

new section on 'Shakespeare's Sources Revisited' (pp. I 39-49). ${ }^{5}$

Not all sources are created equal, however, and the above articles use the same noun to identify both the local (the origin of a line) and the large (the origin of plot and character). Further, we continue to look for sources even as methodology for assessing or admitting them remains undertheorized. Although post-structuralism has given us the giddy proposal that every text is and can only be a tissue of citations authored by the limited cultural resources of the literary language rather than by any particular individual authorial agent, this permissive textual interplay has had little impact on, for example, the kinds of sources cited in an appendix to a modern critical edition. David Scott Kastan's appendix to his 2002 Arden 3 edition of 1 Henry $I V$ identifies the problem: 'it is not so apparent what should be considered as a source', but he goes on, apparently pragmatically: 'the dependence upon an earlier text for plot or sometimes character, is what marks that text as source'. ${ }^{6}$ Despite the methodological shrug, therefore, Kastan's sources for the play - Holinshed, Daniel, The Famous Victories - are precisely those listed by R. P. Cowl and A. E. Morgan in the first Arden edition of the play in I9I4 and again in A. R. Humphreys' Arden 2 edition of 1960, and they do the same intellectual work. ${ }^{7}$ Source study, unlike its Edwardian scholarly contemporaries, has not substantively revisited its intellectual foundations during the course of the twentieth century: whereas everything else about New Bibliography has been re-examined, source study has been remarkably resistant to reassessment. Geoffrey Bullough's still unchallenged Narrative and Dramatic Sources of Shakespeare, published between I957 and I975, has its feet firmly in the amateur criticism of the eighteenth and nineteenth centuries, decrying the modern 'cult of the $\mathrm{PhD}$ thesis' which has 'led to exaggerated claims for obscure and doubtful analogies'. Bullough offered only minimal explanation of his own scholarly procedures in the General Conclusion appended to his eighth volume: 'I have limited my scope to narrative and dramatic sources of some degree of probability and have also printed analogues which may suggest how Shakespeare's contemporaries and predecessors approached similar topics, and also how individual or traditional his treatment was. ${ }^{8}$ Many of us accustomed to using Bullough may not have been fully conscious of what he intended by that distinction between 'source' and 'analogue', since that information is withheld until the final volume in the series.

A recent development is the qualification of the word 'source'. Thus, Thomas and Tydeman talk of 'major' sources - “"major" in the sense that they supplied Marlowe with the bulk of his material'.? Meredith Skura talks of a 'plot source', one that suggests 'a sequence of actions' and Jonathan Bate talks of a 'direct source' by which he means 'the sort that Arthur Brooke's translation of Bandello was for Romeo and Juliet'. ${ }^{\text {Io }}$ The editors of the Arden 3 Tempest distinguish between a 'principal source for [the play's] plot', a 'cluster of sources for its central themes', and 'general sources... for... minor themes, some of its characterizations and some of its language' (309). Clearly, the stand-alone word 'source' has outlived its usefulness.

An explosion of new terms, influenced by more theoretical ideas of intertextuality, has recently been added to the conventional vocabulary for textual relationships which now ranges

5 Austen Saunders, 'A New Source for The Tempest? Richard Cosin's Conspiracie for Pretended Reformation (I 592)', Notes E Queries, 59 (2012), 547-9; Todd Borlik, 'Caliban and the Fen Demons of Lincolnshire: The Englishness of Shakespeare's Tempest', Shakespeare, 9 (2013), 25-5I.

6 David Scott Kastan, ed., 1 Henry IV, Arden Shakespeare (London, 2002), pp. 339-40.

7 William Shakespeare, The First Part of King Henry the Fourth, ed. R. P. Cowl and A. E. Morgan (London, I9I4), pp. xiixxii; William Shakespeare, The First Part of King Henry the Fourth, ed. A. R. Humphreys (London, I960), pp. xxi-xxxix.

${ }^{8}$ Geoffrey Bullough, Narrative and Dramatic Sources of Shakespeare, vol. 8 (London, I975), pp. 342, 346.

9 Vivien Thomas and William Tydeman, Christopher Marlowe: The Plays and their Sources (London, I994), p. 4.

Io Meredith Skura, 'What Shakespeare Did to Marlowe in Private: Dido, Faustus, and Bottom', in Christopher Marlowe the Craftsman: Lives, Stage and Page, ed. Sarah K. Scott and Michael Stapleton (Aldershot, 2010), pp. 79-90; p. 86; Jonathan Bate, Shakespeare and Ovid (Oxford, I994), p. 240. 


\section{HOW SHAKESPEARE READ HIS MARLOWE}

widely: 'origins', 'genesis', 'borrowings', 'senseimpressions', 'materials from which a writer has clearly derived stimulus and motivation' (Thomas and Tydeman), 'echoes', 'traditions', 'inherited sets of expectations, reflexes and conventions' (Miola), 'influence' (Vaughan and Vaughan), an 'originary event' (Dawson), 'line of descent', 'signature technique' (Tudeau-Clayton), 'echo chamber' (Dennett), 'model' (Charney), 'performance citation' (Carlson), 'reaction' (Bradbrook), 'invitation' (Pitcher), 'verbal seepage' (Wiggins), 'discursive environment' (Siemon), 'provocative agent' (Brooke), 'indebtedness', 'indirect influence', 'stimulus' (Paster), 'genealogical link' (Hamilton), 'traffic', 'data' (Clare), 'meme' (Dawkins). ${ }^{\text {II }}$ But source studies are still without the rethinking this lexis implies and the apparatus of the standard edition still reprints the same examples. Reviewing the plausibility of suggested new sources for The Tempest, the Vaughans revert to Bullough's Narrative and Dramatic Sources of Shakespeare as the ultimate authority: "we concur with Bullough [that Jacob Ayrer's I6I 8 play] "throws little light upon Shakespeare's play"” (p. 56).

Accounts of Greenblatt's much-quoted 'elephant's graveyard' of source study seem to suggest, with the Vaughans, that this intellectual stasis is because we have not found many entirely convincing new sources for Shakespeare, whereas perhaps the blockage is in our limited practical understanding of what a source might be. Introducing the Aeneid as 'a text to which we somehow must refer when talking about The Tempest', Donna Hamilton queries her own instinctive vocabulary: 'clearly, we would have all sorts of problems were we to claim...that the Aeneid is the source for The Tempest'. Part of the problem, she realizes, is that 'the story line of The Tempest does not match from beginning to end the story line of the Aeneid' and Jonathan Bate makes the same objection: "it is extremely difficult to make the pattern fit'. ${ }^{\text {I2 }}$ Furthermore, traditional source study does not have room for cognitive theory in which memories can be distorted or in which material one reads earlier in life remains with one longer. Petrarch reports that he 'swallowed as a boy what I would ruminate upon as an older man. I have thoroughly absorbed these writings, implanting them not only in my memory but in my marrow, and they have so become one with my mind that were I never to read them for the remainder of my life, they would cling to me, having taken root in the innermost recesses of my mind.' ${ }^{3}$ Colin Burrow is unusual in proposing a category of 'inspired misremembering', arguing that 'misremembering and mislearning... can be as much a response... as careful imitation and artful echoes'. His focus is Shakespeare's classical learning ('the subject of Shakespeare's classical learning cannot be approached simply by

II Thomas and Tydeman, Christopher Marlowe, pp. I-2; Robert S. Miola, Shakespeare's Reading (Oxford, 2000), pp. I3, I4, I69; Vaughan and Vaughan, eds., The Tempest, p. I48; A. B. Dawson, “"The Arithmetic of Memory": Shakespeare's Theatre and the National Past', in Shakespeare Survey 52 (Cambridge, I999), pp. 54-67; p. 54; Margaret Tudeau-Clayton, 'Wearing "wonder-wounded hearers": Shakespeare's emancipatory poetics', paper delivered at SAA, Toronto, 20I3; Daniel C. Dennett, Kinds of Minds: Toward an Understanding of Consciousness (New York, I996), p. I55; Maurice Charney, 'The Voice of Tamburlaine in Early Shakespeare', Comparative Drama, 3I (I997), 2I3-23; p. 213; Marvin Carlson, The Haunted Stage: Theatre as Memory Machine (Ann Arbor, MI, 2003), p. I I; M. C. Bradbrook, 'Shakespeare's Recollections of Marlowe', in Philip Edwards, Inga-Stina Ewbank and G. K. Hunter, eds., Shakespeare's Styles: Essays in Honour of Kenneth Muir (Cambridge, I980), pp. I9I-204; p. 203; John Pitcher, 'A Theatre of the Future: The Aeneid and The Tempest', Essays in Criticism, 34 (I984), I93-2I5; p. I99; Martin Wiggins, Shakespeare and the Drama of his Time (Oxford, 2000), p. 2; James R. Siemon, ed., Richard III (London, 2009), p. 28; Nicholas Brooke, 'Marlowe as Provocative Agent in Shakespeare's Early Plays', in Shakespeare Survey 14 (Cambridge, I96I), pp. 34-44; p. 34; Paster, pp. 9I, 92; Donna B. Hamilton, Virgil and 'The Tempest': The Politics of Imitation (Columbus, Ohio, I990), p. 4; Janet Clare, Shakespeare's Stage Traffic (Cambridge, 20I4), p. 2; “"Art to Enchant": The Tempest, Sources and Sorcery', paper given at ISA, Stratford, August 2014 (see below, pp. I09-I7); Richard Dawkins, The Selfish Gene (Oxford, I989), p. I92.

I2 Donna B. Hamilton, 'Defiguring Virgil in The Tempest', in Critical Essays on Shakespeare's 'The Tempest', ed. Virginia Mason Vaughan and Alden T. Vaughan (New York, I998), pp. I7-38; p. I7; Bate, Shakespeare and Ovid, p. 244.

I3 Francesco Petrarch, Letters on Familiar Matters: Rerum familiarium libri XVII-XXIV, trans. Aldo S. Bernardo (Baltimore and London, I985), pp. 212-I3. 


\section{LAURIE MAGUIRE AND EMMA SMITH}

the tabulation of sources' ${ }^{\text {I4 }}$ ) but his concept (and caveat) is applicable to source study generally.

In most cases of source study, however, the strength of any claim to have identified a potential source - its proof of concept - is based on the evident continued legibility of that source in the text. This in itself causes problems, as R. S. Miola notes in his discussion of verbal echoes: 'one scholar's echo, signalling indebtedness, is another scholar's coincidence, signifying nothing' (pp. I 3I4). The concept of equivalence or closeness (parallel passages must be demonstrably parallel) was an inevitable premise of twentieth-century source study, influenced as it was, first by the quantifying predilections of early New Bibliography and then by the pattern-recognition skills of Bullough's wartime scholarship.

The governing idea that the source text should remain visible in the target text diverges in significant ways from early modern understandings of the way the writer should deploy his reading. Jonson's injunction in Discoveries appropriately combines a number of commonplaces to instruct the poet how 'to convert the substances or riches of another poet to his own use'. Jonson envisages imitatio as paradoxically a copy of, and a transformation of, the original. On the one hand, the poet is 'to make choice of one excellent man above the rest, and so to follow him till he grow very he'; on the other, he is 'to draw forth out of the best and choicest flowers, with the bee, and turn all into honey'. ${ }^{\text {Is }}$ Petrarch described this as the difference between reading 'hastily and quickly' so that 'these really belong to others, and I have them in my possession with the awareness that they are not my own', and the 'leisurely' reading such that 'I may forget whose they are and whether they are mine or others'. ${ }^{16}$

The most extensive description of this humanist paradox is in Johannes Sturm's I 549 Nobilitas Liberata, published in an English translation in I 570. ${ }^{17}$ Sturm explains to his readers that 'imitation is not in things that be all one, but in things that be like, and that which is like, must be, not the same, but another thing'. The writer's technical and artistic skill is in 'hid[ing] and cover[ing] lyke thinges by unlike using and handling'. ${ }^{18}$ An author's greatest dependence on a source may obscure the visibility of that source. Prospero's description of his usurping brother is a perfect description of this process of imitatio: he 'new created / The creatures that were mine' (I.2.8 I-2).

Stuart Gillespie's entry on Marlowe in his Shakespeare's Books at times comes close to this early modern idea: he moves from identifying traditional Marlowe 'echoes' in Midsummer Night's Dream through the more distant Marlovian 'manner' in Titus Andronicus to the Jew of Malta being the source 'for the atmosphere, though not the plot' of the Jessica-Shylock relationship in Merchant of Venice. He argues that by I 599 (the date of As You Like $I t)$, 'Marlowe's presence is so spectral that it is not clear whether Shakespeare's audience is meant to register it'. ${ }^{\text {I9 }} \mathrm{He}$ then offers the generally agreed exception to this argument: Dido Queen of Carthage, where Aeneas's tale of the fall of Troy is retold by the Player in Hamlet (I60 I-02). Gillespie juxtaposes indistinct haunting with apparently clear citation. We want to develop and unite these notions. For us, Dido Queen of Carthage is not a Hamlet-specific citation but a text which haunts Shakespeare throughout his career. And he continues to engage with it as late as (and perhaps most subtly in) The Tempest.

In proposing Dido Queen of Carthage as a more thoroughgoing and systemic source for The Tempest than has previously been identified, we are trying also to investigate some of the assumptions of source study. We are also proposing a more agonistic relationship between Marlowe and Shakespeare

I4 Colin Burrow, 'Shakespeare and Humanist Culture', in Shakespeare and the Classics, ed. Charles Martindale and Tony B. Taylor (Cambridge, 2004), pp. 9-27; pp. I4, I5, 22.

Is Ben Jonson, Discoveries, ed. Lorna Hutson, in The Cambridge Edition of the Works of Ben Jonson, ed. David Bevington, Martin Butler and Ian Donaldson, vol. 7 (Cambridge, 20I2), pp. $582-3$.

I6 Petrarch, Letters, pp. 2I2-I3.

17 See chapter I of Hamilton's Virgil and 'The Tempest' for an excellent analysis of this text.

I8 Sturm, sig. Hiv; sig. G4r.

I9 Stuart Gillespie, Shakespeare's Books: A Dictionary of Shakespeare's Sources (London, 2001), pp. 324-5, 327. 


\section{HOW SHAKESPEARE READ HIS MARLOWE}

than is traditionally promoted. Shakespeare's poetic engagement with Marlowe's legacy is a narrative told in different ways - as a story about the development of blank verse as a dramatic medium, for example, or as a competition at the level of parallel individual dramas such as Edward II and Richard II, or even, as Harold Bloom allows but then dismisses in the preface to the second edition of The Anxiety of Influence, a strong precursor. ${ }^{20}$ Bloom's language of Shakespeare's 'triumph', 'emancipation' and 'exorcism' sees Shakespeare's 'struggle with poetic influence fully resolved' in the reference to the 'dead shepherd' of As You Like It. ${ }^{2 \mathrm{I}}$ All critics who write on Marlowe's influence on Shakespeare identify a point at which Shakespeare decisively becomes his own man. That point is sometimes seen as I 599 (As You Like It), sometimes identified as late as The Tempest. ${ }^{22}$ In substituting Dido for Faustus as the dominant Marlowe Ur-text of The Tempest, we identify Shakespeare's relation to his brilliant rival as distinctly unresolved even at the end of his career, and we also suggest a different model of memory at work in source studies. This, then, is an article not about what Shakespeare read (or saw) but about how he remembered (and what he could not forget).

\section{DIDO QUEEN OF CARTHAGE AND THE TEMPEST}

Washed up on the island beach and spitefully anatomizing their situation, Antonio and Sebastian query Gonzalo's use of the phrase, 'Widow Dido':

Antonio. Widow? A pox o' that. How came that 'widow' in? Widow Dido!

Sebastian. What if he had said 'widower Aeneas' too?

(2.I.82-4)

We are not the first to pause over this dialogue. Tony Tanner calls it 'pointless banter', Deanne Williams says it is 'curiously aimless' and Frank Kermode finds it unparalleled for 'irrelevance' in the entire Shakespeare canon. ${ }^{23}$ Some critics take the allusion in very general terms: the passage is simply an instruction to 'remember the Aeneid', says Jan Kott. ${ }^{24}$ For others the dismissive helplessness of historical distance is all that can be proffered: 'The whole passage may well have held a meaning for Shakespeare's contemporaries that is lost to us', although Kermode conceded the possibility that 'an understanding of this passage will modify our image of the whole play'. ${ }^{25}$

Adrian follows Antonio and Sebastian's derisory interrogatives with a more reflective line that cues further discussion: "WWidow Dido", said you? You make me study of that' (2.I.86-7). We will try to answer our larger question, 'What is a source?', by moving from Shakespeare to Marlowe/Virgil and then to larger considerations of memory and influence.

The Dido passage in the Tempest gets twentyfive lines of discussion. That the passage is not incidental or irrelevant can be seen in the way its material is reinforced by repetition. Dido is stressed six times, and Carthage three times:

20 The play-for-play approach is seen most obviously in Marjorie Garber, 'Marlovian Vision/Shakespearean Revision', Research Opportunities in Renaissance Drama, 22 (1979), 39; Robert A. Logan, Shakespeare's Marlowe: The Influence of Christopher Marlowe on Shakespeare's Artistry (Aldershot, 2007) and Gillespie, Shakespeare's Books, pp. 324-7.

2I Harold Bloom, The Anxiety of Influence: A Theory of Poetry, 2nd edn (Oxford, 1997), pp. xliv, xliii, xliv. For James Shapiro, this moment when Shakespeare 'explicitly acknowledg[es] and identif[ies] a literary rival for the first and only time in a play or poem' represents Shakespeare's relegation of Marlowe to the past, his digestion of Marlowe's lyric poetry now being 'virtually complete' (Rival Playwrights; Marlowe, Jonson, Shakespeare (New York, I99I), pp. I02, I I7).

22 'Marlowe may well have been on Shakespeare's mind in subsequent comedies and romances; but the pressure of his lyric and comic worlds was past by I600' (Shapiro, Rival Playwrights, p. I I7); 'It was not until his very last sole-authored play that Shakespeare came to final grips with Dr Faustus' (Jonathan Bate, The Genius of Shakespeare (London, I997), p. I29).

23 Tony Tanner, Prefaces to Shakespeare (Cambridge, MA, 20Iо), p. 804; Deanne Williams, 'Dido, Queen of England', ELH, 73 (2006), 3 I-59; p. 5I; Frank Kermode, ed., The Tempest (London, I956), pp. 46-7.

24 Jan Kott, 'The Aeneid and The Tempest', Arion, n.s., 3 (I978), $424-5$ I.

25 Anne Barton, ed., The Tempest (Harmondsworth, I968), p. I53; Kermode, ed., The Tempest, p. 47. 


\section{LAURIE MAGUIRE AND EMMA SMITH}

Adrian. She was of Carthage, not of Tunis.

Gonzalo. This Tunis, sir, was Carthage.

Adrian. Carthage?

Gonzalo. I assure you, Carthage.

(2.1.87-90)

Shakespeare knew his Virgil and certainly he used Virgil in The Tempest - the disappearing feast removed by harpies comes from Book 3 of the Aeneid and when Ferdinand encounters Miranda in Act I he quotes Aeneas ('o dea certe', Aeneid I.328; 'most sure the goddess', Tempest I.2.423). ${ }^{26}$ But there is also a dramatic source close to hand as it happens, a dramatic version of Virgil: Marlowe's Dido. The Tempest has long been seen as a play without a major source: we want to investigate those repeated references as signposts to Marlowe's Dido, Queen of Carthage.

The lexical parallels are many, as are the dramatic parallels in situation. We'll begin, traditionally, with parallel passages, moving on to situational and dramatic echoes, although the three are often interlinked:

I. Venus reassures the distressed Aeneas:

And for thy ships which thou supposest lost, Not one of them hath perisht in the storm.

$$
(D Q C, \text { I.I.235-6) })^{27}
$$

Prospero reassures the distressed Miranda that:

there is no soul -

No, not so much perdition as an hair

Betid to any creature in the vessel

Which thou heard'st cry, which thou sawst sink

(Tempest, I.2.29-32)

And Prospero is later given similar reassurance by Ariel:

Prospero. But are they, Ariel, safe?

Ariel. Not a hair perished.

(Tempest, I.2.217)

2. When the shipwrecked Trojans first enter in I. I, Achates tries to cheer Aeneas:

Doe thou but smile and clowdie heaven will cleare Whose night and day descendeth from thy browes.

(DQC, I.I.I55-6)
At the identical point in The Tempest Gonzalo tries to cheer the bereaved King Alonso:

It is foul weather in us all, good sir, When you are cloudy. (Tempest, 2.I.I $47-8)^{28}$

3. Here is Marlowe's Dido offering herself to Aeneas and holding back from him. Aeneas has asked her what she 'may desire / And not obtaine' $(3 \cdot 4 \cdot 7-8)$. She replies:

The thing that I will dye before I aske And yet desire to have before I dye.

(DQC, 3.4.9-IO)

Here is Miranda in The Tempest, simultaneously offering herself to Ferdinand, and holding back from him, torn between desire and modesty. She weeps, she says,

At mine unworthiness, that dare not offer What I desire to give, and much less take What I shall die to want.

(Tempest, 3.I.77-9)

The similarity of situation makes this a dubious parallel by New Bibliographical textual rules. But the situation is very specific in its similarity: both Miranda and Dido think they have fallen freely in love when each is in fact a plaything of a higher power - the classical gods or a Milanese magician. And consider the rhythm and the rhetoric: the antithesis is striking - not one but two antitheses. Shakespeare is learning

${ }^{26}$ For further parallels with the Aeneid see Pitcher, 'A Theatre of the Future', I93-2I5; Hamilton, Virgil and 'The Tempest', pp. 22-6; Vaughan and Vaughan, eds., The Tempest, pp. 56-8; David Lindley, ed., The Tempest (Cambridge, revised edition, 2OI3), appendix 2.

27 All references to Dido, Queen of Carthage are from Roma Gill, ed., The Complete Works of Christopher Marlowe, vol. I (Oxford, I986).

28 Conceptual blending in which facially expressed emotions are linked to weather is not uncommon, as in King John: 'A fearful eye thou hast... / So foul a sky clears not without a storm; / Pour down thy weather: how goes all in France?' (4.2.106, I08-9). What is unusual in the examples from Dido and Tempest is the symbiosis: Aeneas's and Alonso's emotions affect their companions' emotional weather. 


\section{HOW SHAKESPEARE READ HIS MARLOWE}

an acoustic, a strategy and a rhetorical strategy is a kind of source. ${ }^{29}$

4. The dramaturgical set ups in Dido and The Tempest are also the same. A group of shipwrecked travellers is split in two, each ignorant of the other's survival. When one group of Trojans first meets Aeneas, they recognize him only by his voice - but then discount that recognition:

I heare Aeneas voyce, but see him not,

For none of these can be our Generall.

(DQC, 2.I.45-6)

In The Tempest, Trinculo encounters his companion Stephano, recognizing him by his voice and then discounting this recognition:

I should know that voice. It should be - but he is drowned.

(Tempest, 2.2.87-8) $)^{30}$

From linguistic parallels to situational parallels:

5. In Dido, Cupid performs his sleight of hand with the arrow on Dido's breast/heart under instruction from Venus. It is entirely his own mischief that makes him do the same with the Nurse. In The Tempest, Ariel acts under instruction from the supernaturally powerful Prospero; it is entirely his own mischief that makes him impersonate Trinculo in 3.2 .

6. Achates' attempt to cheer up Aeneas by extolling the virtues of the shore on which they have been shipwrecked (pleasant air and fertile soil; I. I. I 78-9) is paralleled in Adrian and Gonzalo's positive comments about the island's air and green grass, 'advantageous to life' (2.I.37, $49,52)$.

7. Aeneas's long narrative to Dido is a tale of loss, of exile from the city. So too is Prospero's to Miranda.

8. J. B. Steane calls the world of Dido a 'lotosland where men are spellbound as children and all are enticed into forgetfulness'. ${ }^{\text {II }}$ Tony Tanner notes the same of the Tempest: 'the island is full of sleep, could itself be asleep and dreaming. A "strange drowsiness", "wondrous heavy", (2.I.202-3) is everywhere. Many scenes end in sleep or trance. ('They fell together all... they dropped as by a thunderstroke', 2.I.207-8), and by the end you feel the difference between waking and dreaming is terminally blurred. ${ }^{32}$

Steane, who anticipated us in several of the parallel passages we have noted, concluded that 'Shakespeare had a copy of Dido or knew it well, that the memory remained with him as late as The Tempest, and that few contemporary plays moved him more than this'. ${ }^{33}$ We will come back to this play's influence on Shakespeare throughout his canon, but now we want to turn to Marlowe. We need first to recap the relationship between Marlowe's play and its Virgilian source. In part our argument suggests that Dido is so resonant for Shakespeare because it is itself so conscious of its source: it is a source about sources. ${ }^{34}$

\section{Aeneas}

All Dido critics agree that Marlowe's Aeneas is not Virgil's. He is weak, vacillating, mendacious, a poor father, neglectful of women, lacking in

29 As William Empson knew: commenting on a parallelism in Shakespeare's Sonnet 58 ('Be where you list' // 'Do what you will'), he noted the way these lines have the rhythm of a sonnet by Philip Sidney and concluded that Shakespeare structured them 'after his model' in Sidney (Seven Types of Ambiguity (London, 1984), p. 86).

30 It might be thought that this parallel is merely the similarity of situation, and that therefore any shipwreck play might produce a similar effect. But sampling Anon's The Thracian Wonder, Greene and Lodge's A Looking Glass for London, and Heywood's The Captives suggests that the echo in The Tempest is distinctive.

3I J. B. Steane, Marlowe: A Critical Study (Cambridge, I964), p. 39 .

32 Tanner, Prefaces, p. 8 Io.

33 Steane, Marlowe, p. 55.

34 Current textual expertise finds no evidence to believe the I 594 quarto's identification of Nashe as Marlowe's co-author although Gary Taylor notes that Marlowe and Nashe are very hard to tell apart ('Imitation or Collaboration? The Early Shakespeare Canon', paper delivered at ISA, Stratford, August 20I4). Clare Harraway notes the irony of the title page's dual ascription: it 'multiplies points of origination in a process which only serves to accentuate critical anxieties about indebtedness': Re-Citing Marlowe (Aldershot, 200o), p. II 4 . 


\section{LAURIE MAGUIRE AND EMMA SMITH}

any confident sense of Trojan identity or destiny. When Virgil's Dido meets him, Aeneas declares, 'I am Aeneas of Troy' ('adsum, / Troïus Aeneas'). Marlowe's Aeneas says, 'Sometime I was a Troian, mightie Queene, / But Troy is not, what shall I say I am?' (2.I.75-6). Virgil's Aeneas, despite his shipwreck, is glorious: 'godlike in face and shoulders: for his mother herself had shed upon her son the beauty of flowing locks, with youth's ruddy bloom, and on his eyes a joyous lustre; even as the beauty which the hand gives to ivory'. ${ }^{35}$ Marlowe's Aeneas is so bedraggled that Ilioneus does not recognize him. Dido comments on his 'base robes' (2.I.79) and has to dress him up. In speech, Aeneas constantly stresses his abjectness and, as Don Cameron Allen notes, rivals Uriah Heep in his 'umbleness. ${ }^{36}$ Dido repeatedly corrects him:

Remember who thou art; speake like thy selfe:

Humilitie belongs to common groomes.

(2.I.IOO-I; our emphasis)

But Aeneas has no self to speak like. He is emptied out: not 'pious' Aeneas, not 'golden-tongued' Aeneas, not 'warlike' Aeneas. ${ }^{37}$ In Act 4, Marlowe's Aeneas resolves to sail away, citing destiny; but what in Virgil is filial obedience, Marlowe presents as a 'slippery abdication of responsibility'. ${ }^{38}$ Aeneas offers four unconvincing justifications in twenty lines: destiny calls him; Jove wills it; his mother wills it; the Fates bid (4.3.I-2I). Marlowe turns Virgilian destiny into bathos.

These differences from Marlowe's source in Virgil are concentrated in 2.I when Aeneas narrates the downfall of Troy. In Virgil this tale of destruction is not one of finality but of loss leading to a new beginning, a secular felix culpa; Creusa appears to Aeneas and tells him to move forward. The details of the destruction are few, and mostly summary. Whereas in Virgil Aeneas's suffering stems from the 'displaced Trojans' wandering', in Marlowe it is about the 'violence of Troy's downfall'. ${ }^{39}$ Marlowe adds brutality, piling up gory detail upon gory detail. The details are unflinching: 'Yong infants swimming in their parents bloud, / Headles carkasses piled up in heapes,/
Virgins halfe dead dragged by their golden haire' (2.I.I93-5); Pyrrhus 'tooke his fathers flagge,/ And dipt it in the old Kings chill cold bloud, / And then in triumph ran into the streetes, / Through which he could not passe for slaughtred men' (2.I.259-62).

In Carthage, Marlowe's Aeneas knows that this will not be an easy story for him or for his auditors. Dido initially asks Aeneas to speak simply so that she may resolve two competing accounts:

For many tales goe of that Cities fall, And scarcely doe agree upon one poynt.

(DQC, 2.I.IO8-9)

Aeneas warns her that she has requested 'a woefull tale' - merely the 'memory' of Troy's destruction makes him faint. Dido's response is intriguing:

What, faints Aeneas to remember Troy, In whose defence he fought so valiantly?

(2.I.I I 4, I I7-I8)

To paraphrase her lines: 'In Virgil you were triumphant. Remember that.' She is collating the man who speaks to her with his Virgilian source. She does this again at the end of Aeneas's speech, when she, Anna and Iarbas ask further factual questions. 'What became of aged Hecuba?' asks Anna.

35 Virgil, The Aeneid I-VI, trans. H. Rushton Fairclough, rev. G. P. Goold (Cambridge, MA, I9I6, rev. I999), I.595-6, pp. 302-03.

${ }^{6} 6$ Don Cameron Allen, 'Marlowe's Dido and the Tradition', in Essays on Shakespeare and Elizabethan Drama in Honor of Hardin Craig, ed. Richard Hosley (London, I963), pp. 5568; p. 166.

37 Asked who the stranger is, Ilioneus identifies him as 'warlike Aeneas' but Dido refutes this description: 'Warlike Aeneas and in these base robes!' (2.I.79). (Deanne Williams accepts Ilioneus' description; see Williams, 'Dido, Queen of England', p. 46.)

$3^{8}$ Williams, 'Dido, Queen of England', p. 47.

39 Timothy D. Crowley, 'Arms and the Boy: Marlowe's Aeneas and the Parody of Imitation in Dido, Queen of Carthage', English Literary Renaissance, 38 (2008), 408-38; p. 4I6. Marlowe was not yet eight years old when Huguenot refugees from the St Bartholomew's Day massacre flooded into Canterbury. 


\section{HOW SHAKESPEARE READ HIS MARLOWE}

'How got Aeneas to the fleet again?' asks Iarbas. 'But how scapt Helen, she that causde this war?' asks Dido (2.I.290-2). ${ }^{40}$

Aeneas's omission of Helen is notable given the prominence accorded her in his account in Virgil. Aeneas catches sight of Helen, flattened against the wall inside the temple of Vesta. She is terrified. Aeneas wants revenge on Helen for the destruction of his city and, in a long internal dialogue, he debates whether there is glory in attacking a woman. He concludes that in this case, yes, there is, because it is punishment for her wickedness. Killing her will prevent her returning in triumph to Greece. He is not only angry with Helen but aware of his anger. Venus then appears to him to check his wrath. In another long passage she explains the need to control his fury, to focus on the future, and she says the gods are to blame not Helen. Helen is a lengthy focal point in Virgil.

The questions posed by Marlowe's Dido and Anna are logical - or perhaps illogical - given that Aeneas has not mentioned Helen or Hecuba. Once again, Dido is reminding Aeneas of his source: 'get back to Virgil; give us Book 2'. This, of course, has been Dido's expectation from the moment she saw Aeneas - that he would be Virgil's Aeneas, and that the narrative he will tell is the one we know from the Aeneid.

That this was never going to happen is obvious from Aeneas's arrival in Carthage. He is frozen: in grief, in retrospection, unable to move on emotionally from Troy. He compares himself with Niobe, not only a model of grief but a model of stasis: a statue. Without Troy and its king, Aeneas is nothing: 'when I know it is not [Priam], then I die'. Memory of Troy, triggered by the walls of Carthage, is 'not cathartic but traumatic'. ${ }^{4 \mathrm{I}} \mathrm{He}$ fantasizes not about returning to Troy and avenging himself on the Greeks but about Priam doing this. Aeneas is washed up in more ways than one. When Achates reminds him that Priam is dead (and 'Troy is sackt' adds Aeneas), Aeneas responds with the classic statement of survivor guilt: 'And why should poore Aeneas be alive?' (2.I.33-4).

It is the moment of horror when his city is destroyed and its citizens butchered that he replays in his tale to Dido. This is not the narrative she has requested - a narrative of factual clarification; it is not the narrative Virgil gives us, in which destruction is the beginning of translatio imperii.

\section{What is a source?}

As we have seen, Dido's conscious recollection of the source and the play's self-conscious assessment of its divergences from its Virgilian model make it hard to avoid a discussion of how sources function in the play. Critics are divided about how closely Marlowe follows the Aeneid. Clifford Leech writes that Marlowe 'follows Virgil with at times schoolboy slavishness', while T. M. Pearce judges that one third of the lines are carried over from Virgil, and Roma Gill's Oxford edition includes the play in the volume on 'Translations'; in contrast, J. B. Steane says that "not more than one-seventh or one-eighth of the play follows Virgil with any closeness'. ${ }^{22}$ A similar dispute characterizes the identification of Marlowe's presence in the Player's speech in Hamlet, where critics populate a spectrum between 'Marlovian' and 'non-Marlovian'. Harold Jenkins says that the Player's speech 'seems to echo [Dido] at one or perhaps two points, though I think not more'. H. J. Oliver believes that 'Shakespeare is not only quoting Marlowe but half-affectionately pushing over the verge of absurdity what is only trembling on the brink of it'. James Shapiro thinks Shakespeare stylistically indebted to Marlowe throughout: he 'creates the

$4^{\circ}$ In Virgil Dido does not interject. Instead Aeneas anticipates the one question she might want to ask: 'Perhaps, too, you may inquire what was Priam's fate' ('Forsitan et, Priami fuerint quae fata, requiras' (2.505; pp. 350-I).

4I Efterpi Mitsi, “What is this but stone?" Priam's statue in Marlowe's Dido, Queen of Carthage', Word and Image, 27 (20 I I), 443-9; p. 444.

42 Clifford Leech, 'Marlowe's Humor' in Richard Hosley, ed., Essays on Shakespeare and Elizabethan Drama in Honor of Hardin Craig (London, I963), pp. 69-8I; p. 72; T. M. Pearce, 'Evidence for Dating Marlowe's Tragedy of Dido', in J. W. Bennett, Oscar Cargill and Vernon Hall, eds., Studies in the English Renaissance Drama (New York, 1959), pp. 23 I-47, p. 232; J. B. Steane, Marlowe, p. 52. 


\section{LAURIE MAGUIRE AND EMMA SMITH}

"feel" of a Marlovian speech', exaggerating its stylistic features 'in order to recreate its effects'. ${ }^{43}$

None of the available models of source study seems quite to work. What we are proposing sees Dido's relation to The Tempest in terms taken not from traditional source studies but from the discourses of trauma studies via Freud and Mary Jacobus on the one hand, and from hauntology, via Marvin Carlson and Derrida on the other. Both hauntology and trauma studies allow for the unconscious or unbidden irruption of past texts into the present.

\section{Trauma}

Trauma and the operations of memory are key to the construction of both plays. Dido Queen of Carthage is structured around the trauma of Aeneas's 'wofull tale', 'whose memorie like pale deaths stony mace / Beates forth my senses from this troubled soule' (2.I.II4-I6); a similarly lengthy recollection and reconstruction of the traumatic exile from Milan shapes the opening act of The Tempest. Both Marlowe's Aeneas and Shakespeare's Prospero experience trauma through forms of disrupted memory - flashback, narrative, haunting - and both their plays offer multiple narratives, parodies, echoes and inset art objects we might want to understand collectively as a post-traumatic aesthetic. It's tempting - and not unrewarding - to tick off Aeneas's or Prospero's characterization in their plays against the checklist in the American Psychiatric Association's Diagnostic and Statistical Manual of Mental Disorders for post-traumatic stress disorder - 'recurrent, involuntary, and intrusive distressing memories', 'feelings of detachment or estrangement from others', 'irritable behavior and angry outbursts', 'hypervigilance', 'problems with concentration', 'markedly diminished interest or participation in significant activities', and 'persistent, distorted cognitions about the cause or consequences of the traumatic events that lead the individual to blame him/herself or others'. ${ }^{44}$

Critics who have used modern psychological theories of trauma to think about the literature of this period have tended to focus on characters' psychology - such as, for example, Deborah Willis's important essay on Titus Andronicus. ${ }^{45}$ But in bringing trauma towards source study, the concept is useful not as an attribute of characters but as one of plays: it is located textually, rather than psychologically. We want to understand the relationship between the plays as that between trauma and its later manifestations, and to propose this somatic and psychological model as a new kind of source study. Perhaps we can understand the imaginative hold of Dido across Shakespeare's writing career in terms of a trauma response - we can recast Dido as what trauma theory understands as a 'stressor' rather than a 'source', and then look for its transformed, repressed, unbidden traces in The Tempest. As Aeneas recalls and reconstructs the experience of Troy, or as Prospero fashions the narrative of his overthrow, so The Tempest refers to, is occupied by, and attempts to process, the trauma

43 Harold Jenkins, ed., Hamlet (London, I982), p. 479; H. J. Oliver, ed., Dido, Queen of Carthage and The Massacre at Paris (London, I974), pp. 32-3; Shapiro, Rival Playwrights, pp. I29, I32.

44 American Psychiatric Association, Diagnostic and Statistical Manual of Mental Disorders: Fifth Edition DSM-5 (Arlington, VA, 20I3), pp. 27I-2.

45 Deborah Willis, 'The Gnawing Vulture: Revenge, Trauma Theory, and Titus Andronicus', Shakespeare Quarterly, 53 (2002), 2I-52. See also Matthew Martin, 'Translatio and Trauma: Oedipus, Hamlet and Marlowe's Dido, Queen of Carthage, LIT: Literature Interpretation Theory, 23 (20I2), 30525. Richard Martin identifies Aeneas's trauma without articulating it as such: 'Aeneas reacts with uncharacteristic sensitivity to his own imaginative recreation of the horrors of war', in 'Fate, Seneca and Marlowe's Dido, Queen of Carthage', Renaissance Drama, I I (I980), 45-66; p. 59, our emphasis. Reviewers of the Globe production of Dido (2003) identified Aeneas as traumatized: '[Will] Keen's Aeneas ... suggests repressed trauma in his riveting, hushed account of Greek atrocities' (Kate Bassett, Independent, 24 June 2003); 'a man traumatised by his memories of Carthage' (Charles Spencer, Telegraph, 24 June 2003); 'Aeneas . . s suffers a crisis of identity brought on by trauma, not love' (Michael Caines, TLS, is August 2003). The Arden 3 editors of The Tempest note that Prospero 'wrecks [his enemies'] ship (an ironic recompense for their sending him to sea in a leaky vessel), then traumatizes them' (p. I46). The editors' parenthesis underplays the quid pro quo trauma. 


\section{HOW SHAKESPEARE READ HIS MARLOWE}

of Marlowe's doomed brilliance. We have thought a lot about survivor guilt as a possible psychological paradigm for the late plays, thinking of a Shakespeare in his late forties facing his own retirement and looking back as the last of the generation of writers who shaped his early career Kyd (died I 594), Greene (died I 592), Peele (died I596), Nashe (died c.I60I), Chettle (dead by I607) and, most of all, of his exact contemporary Marlowe: he is now surrounded by younger writers (Fletcher, born I579; Middleton, born I 580 ; Jonson, born I 572). ${ }^{6}$

Thus the source for The Tempest is the alternately receding and intrusive memory of, or even the trauma of, Marlowe's Dido - rather than Dido itself. Memory here is less the photocopy function of having, say, North's translation of Plutarch's Lives open on the table while writing Antony and Cleopatra, or of Brooke being a 'direct source' for Romeo and Juliet. Instead it shares the qualities psychologists attach to traumatic memory: intrusive, detailed, multi-sensory recollections of the stressor; disturbed or partial recall, often unbidden; false or fictive associated memories with a similar affect. The consequence of that redefinition means that the conclusive evidence for the source is not its instant or accurate visibility within the text but rather its distorted and fragmentary emanation.

In fact, we might note, not entirely in passing, that Troy itself plays a significant role in Freudian theories of memory. Freud was fascinated both by the Aeneid and by Heinrich Schliemann's discovery of the ruins of Troy in I 870, and drew on his hero's achievement in his frequent adversion to archaeological metaphors for the unconscious. In a letter to Fliess, Freud likened the psychoanalytic process to 'the technique of excavating a buried city', and elsewhere he exulted in a successful analytic breakthrough recovering childhood memories in 'a persistent patient' with 'It is as if Schliemann had once more excavated Troy, which had hitherto been deemed a fable.' ${ }^{4}$ A young acquaintance's inability to quote Dido's 'famous' line 'Exoriar(e) aliquis nostris ex ossibus ultor' is understood by Freud as a psychic disturbance due to the anxiety that his girlfriend might be pregnant. The example helps Freud to the questions of forgetting, substitution and memory function that preoccupy him in The Psychopathology of Everyday Life. ${ }^{4}$ Freud takes a quotation from the Aeneid as the epigraph to The Interpretation of Dreams, and in the essay 'Screen Memories' he isolates Aeneas's speech to his fellow Trojan exiles: 'Forsan et haec olim meminisse iuvabit' ('Perhaps even this distress it will some day be a joy to recall', 2.203, pp. 276-7) 'as an eloquent affirmation of what he hoped would be the eventual successes of the "talking cure". ${ }^{49}$

For Elizabeth Jane Bellamy, Aeneas's recollection of Troy in the Aeneid is foundational in establishing epic as the 'literary genre most concerned with remembering'. ${ }^{50}$ And certainly references to Troy in early modern England often collocate it with remembering: Sidney's Apology urges 'Only let Aeneas be worn in the tablet of your memory'; Anthony Munday's mayoral pageant Triumphs of Re-United Britannia (I605) has Brute building 'New Troy, in memorie/ Of whence I came'; Thomas Heywood asks 'what pen of note, in one page or other hath not remembered Troy?'. ${ }^{\text {I }}$ Hamlet prompts the Players to that Marlovian remembrance of 'Aeneas' tale to Dido' with 'if it live in your memory, begin at this line' $(2.2 .45 \mathrm{I}-2)$. The long speeches in Dido, Queen of Carthage are

${ }^{46}$ Late Shakespeare seems preoccupied with some of those lost contemporaries: the return to Greene as the source for The Winter's Tale, for instance.

47 J. Moussaieff Masson, ed., The Complete Letters of Sigmund Freud to Wilhelm Fliess, 1887-1904 (Cambridge, MA, I985), letter dated 2I December I899, pp. 39I-2.

$4^{8}$ Sigmund Freud, The Psychopathology of Everyday Life, trans. Anthea Bell (London, 2002), pp. I2-I6.

49 Elizabeth Jane Bellamy, Translations of Power: Narcissism and the Unconscious in Epic History (Ithaca, NY, I992), p. 55. See also Ellen Oliensis, 'Freud's Aeneid', Vergilius, 47 (200I), pp. 39-63.

50 Bellamy, Translations of Power, p. 52.

5I Katherine Duncan-Jones and Jan van Dorsten, eds., Miscellaneous Prose of Sir Philip Sidney (Oxford, 1973), p. 98; Anthony Munday, The Triumphs of Re-United Britannia (London, I605), sig. B3; Thomas Heywood, The Iron Age (London, I632), sig. A2r-v. 


\section{LAURIE MAGUIRE AND EMMA SMITH}

indeed a feat of memory for the Aeneas actor. But The Tempest, too, is preoccupied by memory almost every character is enjoined to 'remember', as the island takes on an aspect of recollection in which geographic and historic distance - the dark backward and abysm of time - are conflated. ${ }^{52}$ As Miranda half-remembers her own childhood: 'Tis far off / And rather like a dream than an assurance / That my remembrance warrants', I.2.44-6). She, like the play's other characters, is being prompted to remember something that happened long before the play began. For the story of The Tempest that something is Prospero's exile from Milan. For the work The Tempest, that something is Marlowe's Dido, Queen of Carthage.

\section{Hauntology}

Although trauma describes Aeneas' state - and perhaps Prospero's too - the word may be too negative for the relationship between the plays and the dramatist-survivor. It is not meant this way. We employ the term in the way trauma theorists do to refer simply to memories of 'an originary event', where the 'something that has already happened acquires meaning after the fact'. As Freud writes, trauma simply describes 'any excitations from outside which are powerful enough to break through the protective shield'.53 It is a commonplace to acknowledge that Marlowe's plays were, to the young Shakespeare at least, powerful 'excitations from outside'. The notion of breached boundaries is developed helpfully, in a different vein, by Derrida who explores memory through the trope of ghosts and haunting - what he names 'hauntology'. Colin Davis glosses Derrida's felicitous coinage in ways that are suggestive for our concern here with the absent presence of the source: 'Hauntology supplants its near-homonyn ontology, replacing the priority of being and presence with the figure of the ghost as that which is neither present nor absent, neither dead nor alive.' 54

We have already noted the prominence of spectral imagery in critical works on Dido and The Tempest. Stuart Gillespie talks of Marlowe's spectral presence in Shakespeare; John Pitcher identifies Virgil as a spectral presence in The Tempest. ${ }^{55}$ Derrida helps us see why this image is so relevant: 'A masterpiece always moves in the manner of a ghost.' It becomes a thing, 'that thing, the Thing that, like an elusive specter, engineers a habitation without proper inhabiting, call it a haunting, of both memory and translation'. Memories do not recognize borders, 'by definition, they pass though walls, these revenants, day and night, they trick consciousness and skip generations'. ${ }^{56}$ Derrida could be paraphrasing Sturm on how hidden sources work in imitatio, and his words certainly characterize The Tempest's relation to Dido and Dido's relation to The Tempest. So too does Derrida's recurrent interrogative refrain: 'Hath this thing appeared again tonight?'

In thinking of memory as a ghost, we may note the insightful verb Shakespeare uses for Old Hamlet's spectre. It 'appears'; it is not summoned. Derrida's spectral concept of memory does not operate as it does for the speaker of Sonnet 30: 'When to the sessions of sweet silent thought / I summon up remembrance of things past' (our emphasis). Ghosts

52 Tony Tanner notes that the verb to 'remember' is used more often in The Tempest than in any other Shakespeare play (p. 809). Evelyn Tribble examines the play's tensions between different forms of memory ("“The Dark Backward and Abysm of Time": The Tempest and Memory', College Literature, 33 (2006), I5I-68. In the Globe production of 2013 characters regularly forgot key details and had to be prompted (e.g. Ariel forgot where Sycorax was born).

53 Dawson, 'Arithmetic', p. 54; Mary Jacobus, Border Crossings: Traumatic Reading and Holocaust Memory (Oxford, 1999), pp. I24, I3 I. Critics describe the Reformation as causing a national trauma; see Patrick Collinson, From Iconoclasm to Iconophobia: the Cultural Impact of the Second English Reformation, Stenton Lecture (Reading, I986); Anthony Dawson, “"Priamus is Dead": Memorial Repetition in Marlowe and Shakespeare', in Peter Holland, ed., Shakespeare, Memory and Performance (Cambridge, 2006), pp. 63-86.

54 Jacques Derrida, Specters of Marx, trans. Peggy Kamuf (New York, I994), p. Io. Colin Davis, 'État Présent: Hauntology, Spectres and Phantoms', French Studies, 59 (2005), 373-9; p. 373 .

55 Gillespie, Shakespeare's Books, p. 327; Pitcher, 'A Theatre of the Future', p. I97.

${ }_{56}$ Derrida, Specters of Marx, pp. I 8, 30. 


\section{HOW SHAKESPEARE READ HIS MARLOWE}

do not respond to commands; the source-spectre Dido comes unbidden and unexpectedly.

When Hamlet decides to 'follow' the ghost, Derrida asks, 'What does it mean to follow a ghost? And what if this came down to being followed by it, always, persecuted perhaps by the very chase we are leading?' His question about circularity, about cause and effect, introduces a specular 'anachrony' as he explains that 'This Thing meanwhile looks at us and sees us not see it even when it is there.' ${ }^{57}$ But in terms of source study it also introduces a temporal anachrony (something we are familiar with from post-structuralism). This anachrony, this 'spectral asymmetry' as Derrida calls it, is particularly relevant to the struggle that Marlowe's and Shakespeare's plays stage with their precursor texts.

Exploring The Tempest's intertextual moments, Barbara Mowat introduces us to the idea of 'infracontext'. Texts and associations intrude on the audience's/reader's awareness, creating (in Claes Schaar's phrasing) a 'vertical context system': recognition is the moment when 'surface contexts, operating as a signal, trigger a memory of the infracontext'. ${ }^{5}$ The beauty of this schema, as Mowat realizes, is its anachrony. It shifts the focus from the source-reading author (and from the source-hunting critic) to the source-recognizing reader. It also allows multiple and even contradictory infracontexts to coexist (thus obviating Hamilton's initial anxiety with a Tempest that 'does not match' its putative source in the Aeneid or Bate's difficulty in making 'the pattern fit'). Infracontexts do not require a pattern. Like ghosts, they come and go. ${ }^{59}$ 'Enter the ghost, exit the ghost, re-enter the ghost. ${ }^{60}$

For Marvin Carlson all drama is about ghosts (as the title of his book, The Haunted Stage indicates) because drama is about memory. Every aspect of theatre is about reappearance: known actors in new roles, new actors in known roles, the redeployment of props, the retelling of familiar stories, the recycling of audiences who carry in 'their collective memory the awareness that drives the theatre experience'. Carlson gives author, text, production, actor and audience equal weight in the ghosting process, although his discussions of author and audience are of particular relevance to our argument. Ibsen gives Carlson his theme: 'all plays might be called Ghosts'; 'ghosting presents the identical thing they have encountered before, although now in a somewhat different context'. ${ }^{6}$ An audience watching The Tempest in I6 I I would have been very aware of this.

Although John Pitcher felt, pessimistically, in I984 that Virgil's exclusion from Bullough meant that the Aeneid would never enter the mainstream as a source for The Tempest, that has not proved to be the case. Jonathan Bate says of Gonzalo's 'widow Dido' allusion that 'Shakespeare [is] vigorously waving a flag marked Aeneid' and Donna Hamilton's book-length study has waved the flag even more vigorously. ${ }^{62}$ The Aeneid is the version of the Dido story with which modern readers are most familiar - Marlowe's play still tends to be dismissed as juvenilia, notwithstanding Martin Wiggins' compelling revisionist argument about dating $^{63}$ - and so the stress on rehabilitating Virgil as context is understandable. But as we will illustrate in the next section, Dido is omnipresent in the Shakespeare canon. Part of The Tempest's complex infracontextual multiplicity is its haunting by not one but two classical predecessors. ${ }^{64}$

57 Derrida, Specters of Marx, pp. Io, 6.

58 Barbara A. Mowat, “'Knowing I loved my books”: Reading The Tempest Intertextually', in Peter Hulme and William $\mathrm{H}$. Sherman, eds., 'The Tempest' and its Travels (London, 2000), pp. 27-36; p. 28.

59 Deanne Williams notes that Prospero's arrival on the island makes him an Aeneas figure, but in giving fresh garments to shipwrecked sailors he is a Dido ('Dido, Queen of England', p. 53). Hamilton finds types of Aeneas in almost all the male characters in the play (p. 26).

60 Derrida, Specters of Marx, p. xx.

6I Carlson, The Haunted Stage, pp. 48, I, 7.

62 Pitcher, p. I99; Bate, p. 243. Even so, editors do not quite know what to do with The Aeneid. The Vaughans devote two pages to Virgil in a section on 'classical models' (pp. 568) whereas David Lindley's New Cambridge edition has an appendix of 'parallel passages from Virgil and Ovid' (Cambridge, revised edn, 2013), appendix 2.

63 Martin Wiggins, 'When did Marlowe write Dido Queen of Carthage?', Review of English Studies, 59 (2008), 52 I-4I.

64 Mowat, "“Knowing I loved my books",' p. 30. 


\section{LAURIE MAGUIRE AND EMMA SMITH}

\section{DIDO AND SHAKESPEARE}

Let us explore Dido, Queen of Carthage across Shakespeare's career. Dido's own self-conscious relation to its source makes it a particularly apt play to attach itself to Shakespeare's imagination. The ongoing influence of Dido is not simply a matter of occasional recall or deployment: this is the play Shakespeare could not forget. Its fingerprints are everywhere, and once we acknowledge that ubiquity, new direct allusions become visible and audible. It can be heard in Julius Caesar when Portia sends Lucius to the Forum with a message, telling him, 'Stay not to answer me, but get thee gone' (2.4.2). Dido, similarly anxious, says the same to Anna when she sends her to the waterside at 4.4.3: 'Stay not to answer me; run, Anna, run'. The half-line command that the plays have in common might seem innocuously formulaic; the fact is, it appears nowhere in early modern drama before I6I I / I623 except in these two plays. ${ }^{65}$ In Richard III Queen Margaret laments that she will die 'neither mother, wife, nor England's queen' (I.3.206). In Dido, King Priam laments that he dies 'neither father, lord, nor king' (2.I.237). In As You Like It, Phoebe conceals the onset of her love for Ganymede by telling Silvius that 'I love him not, nor hate him not' (3.5.I28). In the early stages of love, Dido tells Aeneas cryptically, 'I love thee not - / And yet I hate thee not' (DQC, 3.I.I7I-2). In Comedy of Errors, when Adriana asks her inattentive husband if she has lost her beauty, contrasting his previous devotion with his current neglect, her lines parallel Dido's to Aeneas:

Dido. $\quad$ The time hath been

When Dido's beauty chain'd thine eye to her.

Am I less fair than when thou sawest me first?

O then Aeneas 'tis for grief of thee!

(DQC, 5.I.II3-I6)

Adriana. The time was once when thou unurged wouldst vow

That never words were music to thine ear,

That never object pleasing in thine eye...

Unless I spake, or looked.

(Comedy of Errors, 2.2.I I6-I8, I2I)
And compare with

Hath homely age th'alluring beauty took

From my poor cheek? Then he hath wasted it.

$$
\text { (Comedy of Errors, 2.I.88-9) } 66
$$

In Antony and Cleopatra Cleopatra vacillates, hesitates to speak her emotions, and forgets what she wanted to say:

Sir, you and I must part; but that's not it.

Sir, you and I have loved; but there's not it;

That you know well. Something it is I would -

$\mathrm{O}$, my oblivion is a very Antony,

And I am all forgotten.

(Antony and Cleopatra, I.3.88-92)

In Dido, Dido vacillates, hesitates to speak her emotions, and forgets what she wanted to say:

And yet Ile speake, and yet Ile hold my peace, Doe shame her worst, I will disclose my griefe:

Aeneas, thou art he, what did I say?

Something it was that now I have forgot.

(DQC, 3.4.27-30)

Meredith Skura detects the influence of Dido on A Midsummer Night's Dream, finding it responsible for tone, plot and character: a 'mockery of love's dotage' with 'puppet-like' characters chasing each other in a chain. She also detects verbal parallels: between Titania's bower and Venus's and Dido's bowers, between Dido's and Hermia's serpents and between the two play's magical enchantments where Venus's plans for the sleeping Ascanius ('asleep', 'purple hyacinth', 'milk-white', 'dote') cue Oberon's 'milk-white', 'purple', 'sleeping', 'dote' (Dream, 2.I.I67-7I). ${ }^{67}$

(Non-)coincidences like these mean that when the Shakespeare canon refers to Dido, one has to suspect a source in Marlowe as much as a source

65 Dido reuses the line (reversing it: 'Run Anna, run, stay not to answere me') at 5.I.2 IO.

66 See Dorothea Kehler, 'Shakespeare's Recollection of Marlowe's Dido, Queen of Carthage: Two Notes', American Notes and Queries, I4 (2010), 5-Iо.

${ }_{7}$ Skura, p. 82. For further parallels see Williams, 'Dido, Queen of England', pp. 49-50. 


\section{HOW SHAKESPEARE READ HIS MARLOWE}

in Virgil. The Dido references begin at the start of Shakespeare's career. In Titus Andronicus, Lucius is invited to speak

as erst our ancestor

When with his solemn tongue he did discourse

The lovesick Dido's sad-attending ear

The story of that baleful-burning night

When subtle Greeks surprised King Priam's Troy.

(Titus Andronicus, 5.3.79-83)

Earlier in the play Tamora invites Aaron to aprèshunt erotics:

And after conflict such as was supposed

The wand'ring prince and Dido once enjoyed

When with a happy storm they were surprised,

And curtained with a counsel-keeping cave,

We may, each wreathèd in the other's arms,

Our pastimes done, possess a golden slumber. .

$(2.3 .2 \mathrm{I}-6)$

In 2 Henry VI Margaret similarly woos Suffolk with a Dido reference, one that fits more with the antics of Marlowe's Ascanius than with Virgil's:

How often have I tempted Suffolk's tongue ...

To sit and witch me, as Ascanius did,

When he to madding Dido would unfold

His father's act, commenced in burning Troy!

(2 Henry VI, 3.2.I I4-I8)

In The Taming of the Shrew Lucentio's servant and confidant, Tranio, is as dear to him 'As Anna to the Queen of Carthage was' (I.I.I52). In $A$ Midsummer Night's Dream Hermia swears by 'that fire which burned the Carthage queen / When the false Trojan under sail was seen' (I.I.I73-4). All the above references are concentrated in a narrow window in the late 1580 s/early I 590 s, suggesting the immediate influence of Dido. But they continue less overtly.

When Henry V threatens the citizens of Harfleur, his envisaged atrocities include old men's heads dashed against walls, babies spitted on pikes, virgins desecrated (3.3.84-I26). Henry $V$ is usually seen as Shakespeare's attempt to write a Tamburlaine play. In fact, these violent details correspond to
Aeneas's memories of the fall of Troy. When the bloody captain struggles to capture Macbeth's cold savagery he too echoes the play. Aeneas's description of the murder of Priam - 'Then from the navell to the throat at once, / He ript old Priam' (2.I.255-6) - produces both Macbeth's rebel 'unseamed ... from the nave to the chops' (I.2.22) and Macduff from his mother's womb 'untimely ripped' (5.Io.I6). When in Act 5 of Coriolanus the characters discuss Coriolanus's imminent revenge on Rome, they repeatedly envisage the city as burning: Coriolanus's eye is 'red as 'twould burn Rome' (5.2.64); this memorable image is supported by four more references to Rome on fire. The characters' obsession with the city burning is notable since there is no mention of it in Shakespeare's source in Plutarch - perhaps because Plutarch is not Shakespeare's source at this point, but Dido, Queen of Carthage. The references are not just a Shakespeare addition to the account in Plutarch but a Marlowe-Shakespeare addition: Aeneas's description of the sack of Troy makes seven references to the city on fire. When Shakespeare thought of the worst thing he could imagine, he remembered Marlowe's Dido.

We mentioned above Phoebe's riddling line to Silvius in As You Like It as echoing Dido's cryptic comment to Aeneas. Just before this moment, Phoebe quotes Marlowe directly when, having fallen in love with Ganymede, she apostrophizes Marlowe:

Dead shepherd, now I find thy saw of might: 'Who ever loved that loved not at first sight?'

(As You Like It, 3.5.82-3)

James Shapiro cites As You Like It in support of his argument that Shakespeare's response to Marlowe is defined by its belatedness, six years after Marlowe's death. In fact, as we have tried to show, Shakespeare's engagement with Marlowe begins early and runs late. And it is an engagement that specifically centres on Dido.

Richard Martin says that Dido 'is not a work of major literary significance. It did not spark the kind of popular imitations that Tamburlaine and Edward II 


\section{LAURIE MAGUIRE AND EMMA SMITH}

did. ${ }^{98}$ It is not clear whether these two statements are causally connected - that imitations prove the significance of a work. Of course, as we noted at the start of this article, imitations can occlude their origins. But the constant, covert presence of Dido throughout the Shakespeare canon suggests that Shakespeare saw this play as having major literary significance. ${ }^{69}$ James Shapiro is not being fanciful in supposing that Shakespeare, like Hamlet, singled out Dido: 'one speech in it I chiefly loved, 'twas Aeneas' tale to Dido' (Hamlet, 2.2.448-9). ${ }^{70}$

\section{CONCLUSION}

In The Genius of Shakespeare, Jonathan Bate writes that Marlowe is the only contemporary whom Shakespeare 'overtly alludes to rather than subliminally absorbs'; ${ }^{71}$ we think he does both. And when J. B. Steane compared Aeneas's Troy speech in Marlowe with its source in Virgil, he concluded that this 'is the work of a man who has made his Virgil so thoroughly and imaginatively his own that his version of the story is virtually independent of its source'.$^{72}$ That is exactly the relationship we are positing between The Tempest and Dido. Antony Dawson makes a similar point about The Tempest and the Aeneid: 'I don't see Shakespeare wrestling with Virgil but rather inhabiting him. ${ }^{173}$ We would substitute Marlowe for Virgil.

Steane and Dawson have stumbled upon Sturm's definition of source in which the most significant source may be the most thoroughly assimilated, most subliminally absorbed - and therefore the most invisible. But Shakespeare does not want this source to be invisible: invisibility defeats the point of imitatio. Sturm advises writers both to advertise and conceal their source - since the former enables the reader to admire the latter. Discussing Virgil's use of Theocritus, Sturm recommends his method: 'he woulde have it knowne whom he imitateth, although he would not have it spyed, how and after what sort he doth it'. ${ }^{74}$ Donna Hamilton explains the pleasure this experience of cognitive fort-da affords: the reader has the pleasure... in discovering the artistry that the concealment itself promoted'. ${ }^{75}$ Marvin Carlson makes the same point when he discusses drama's recycling of material: 'it encourages audiences to compare varying versions of the same story, leading them to pay closer attention to how the story is told and less to the story itself' ${ }^{76}$ 'Widow Dido' brings the source explicitly into the play so that The Tempest, like Marlowe's Dido, Queen of Carthage can explore the thematic nexus between past and present, remembering and forgetting between originary moments and their aftermath.

\section{Coda}

We might add, by way of coda, that locating Prospero's island prompts almost as much critical ink as identifying the play's source. The play teases us with New World references - the still-vexed Bermudas, Miranda's ‘brave new world', Caliban's anagrammatic name and his Patagonian god, Setebos, Prospero's enslavement of the native,

68 Martin, 'Fate, Seneca and Marlowe's Dido', p. 46.

69 Recent stage history, including productions at the Globe (dir. Tim Carroll, 2003), the site-specific Angels in the Architecture production in St Barnaby's Soho and Kensington Palace (dir. Rebecca McCutcheon, 2007, 2008), the National Theatre (dir. James MacDonald, 2009), and Edward's Boys (dir. Perry Mills, 20I4) also belies Martin's conclusion that Dido is a 'bookish play, better read than viewed' (p. 66). It is not clear whether Shakespeare saw or read the play (or both). On its title page the Quarto, published in I 594, assigns the play to the Children of her Majesty's Chapel, for whom there is no record of London performance between I 584 and I600.

70 Shapiro, Rival Playwrights, p. I3 I.

7I Jonathan Bate, The Genius of Shakespeare (London, 2008), p. I04.

72 Steane, Marlowe, p. 4I (our emphasis).

73 Dawson, 'Priamus', p. 82.

74 Sturm, sig.Hiv. A modern work in a different medium film - illustrates this point: The Imaginarium of Dr Parnassus (2009, dir. Terry Gilliam) is subtly indebted to The Tempest.

75 Hamilton, Virgil and The Tempest, p. I6.

76 Carlson, p. 27. Jackson Cope locates this phenomenon locally when he analyses Dido's fondness for triple effects, for dramaturgical repetition with variation: it requires the audience to react to 'doubleness', to hold 'simultaneous consciousness of actor and role, story world and stage world' (Jackson I. Cope, 'Marlowe's Dido and the Titillating Children', ELR, 4 (1974), 315-25; p. 32 I). 


\section{HOW SHAKESPEARE READ HIS MARLOWE}

Trinculo's plan to exploit him by exhibition. ${ }^{77}$ But it is also markedly Mediterranean - Tunis, Carthage, Algerian Sycorax, Italians en route to Milan and Naples.

Several critics observe that the wedding from which the Italians are returning took place in North Africa. Claribel was married in Tunis, giving us (in a gendered reverse), the happy ending that Virgil and Marlowe decline to provide. $^{78}$ We want to develop these points: we think The Tempest takes place on the way back from Dido,
Queen of Carthage. There has just been a romantic rendezvous in North Africa and the men are on their way to Italy. In other words, the play's geography is suspended between a source and a destination. The Tempest thus lives in a place 'full of noises' (3.2.138), the very space of Shakespeare's imitative and haunted invention.

77 See Bate, Genius of Shakespeare, pp. 242-3).

$7^{8}$ Dawson, 'Priamus', p. 72; Williams, 'Dido, Queen of England', p. 5I. 